\section{Performance of Southern Highbush Blueberry Cultivars Under High Tunnels in Florida}

\author{
Bielinski M. Santos ${ }^{1}$ and Teresa P. Salame-Donoso
}

\begin{abstract}
AdDITIONAL INDEX wORDs. Vaccinium corymbosum, protected agriculture, greenhouses, small fruit, freeze protection

SuMMARY. A study was conducted over two southern highbush blueberry ( Vaccinium corymbosum $\times$ Vaccinium darrowi) seasons in a grower field in Florida. The objective was to compare the early fruit weight of southern highbush blueberry cultivars in high tunnels and in open fields. Four treatments were tested using combinations of two southern highbush blueberry cultivars (Snow Chaser and Springhigh) and two production systems (open fields and 18-ft-high tunnels). The results indicated that there was a significant effect of the production systems on the number of days with air temperatures at or near freezing $\left(\leq 34^{\circ} \mathrm{F}\right)$, and maximum and minimum air temperatures. The minimum air temperature in open-field plots reached $\approx 19$ and $21^{\circ} \mathrm{F}$ (61 freezing or near-freezing events) in the 2009-10 and 2010-11 seasons, respectively, whereas the minimum air temperatures inside the high tunnels were $\approx 32$ and $33^{\circ} \mathrm{F}$, respectively, during the same seasons (only 3 days at $\leq 34^{\circ} \mathrm{F}$ ). This indicated that using high tunnels was an effective means to avoid freezing air temperatures in blueberries. In the first season, the cumulative early fruit weight was the highest in plots planted with 'Snow Chaser' inside the high tunnels ( $\approx 10$ tons/acre), while the combined production of the two cultivars in the open fields did not reach 1 ton/acre until the end of the early harvests. The following year, there were no differences in the cumulative early fruit weight of both cultivars when planted in the open fields (2.2 tons/acre) and the cumulative fruit yields of 'Springhigh' and 'Snow Chaser' growing inside the high tunnels was twice and four times higher, respectively, than the early fruit production obtained in the open fields. These data showed the profound effect of high tunnels on flower protection and fruit set. High tunnels reduced water use for freeze protection. The total volume used in the open fields during the freezing or near-freezing days was $\approx 2.5$ acre-inch/acre per 8 hours of freeze protection, whereas only $1 / 10$ of that volume was applied inside the structures.
\end{abstract}

$\mathrm{I}$ n 2010, U.S. blueberry (Vaccinium sp.) production occurred on nearly 68,400 acres (Joshua, $2010)$. In Florida, $\approx 3500$ acres were planted with a crop value of near $\$ 50$ million in 2010 (Florida Department of Agriculture and Consumer Services, 2011). Southern highbush blueberry farms are disseminated throughout Florida from the northern border with Georgia (lat. $30^{\circ} 33^{\prime} \mathrm{N}$ ) to the southwest region (lat. $26^{\circ} 38^{\prime} \mathrm{N}$ ), which comprises most of the cool temperature areas in late fall, winter, and early spring. Blueberries are transplanted in open fields either into plasticcovered or bare soil hills, which are irrigated with sprinklers, mini-sprinklers, or drip lines. The soils in the majority of the southern highbush blueberry growing areas are sandy with rapid

Gulf Coast Research and Education Center, IFAS, University of Florida, 14625 County Road 672, Wimauma, FL 33598

The authors thank the support of Straughn Farms on the completion of this study.

${ }^{1}$ Corresponding author. E-mail: bmsantos@ufl.edu. drainage and slightly alkaline $\mathrm{pH}$. Planting hills are formed with pine bark or with a mix of pine bark rototilled into the sandy soil. These practices are aimed to lower soil $\mathrm{pH}$ because of the pine bark acidity $(\mathrm{pH}<6)$ and to promote rapid drainage during the rainy summer months. Planting densities vary depending on the cultivars but the most common are between 1600 and 2800 plants/acre (Lyrene and Williamson, 1997). Flowering of southern highbush blueberry occurs from January to March and most of the planted cultivars in Florida have chilling requirements between 200 and $400 \mathrm{~h}$ per winter with temperatures $\leq 45^{\circ} \mathrm{F}$. Those required chilling hours may be obtained depending on the location of the fields in the state. Fruit are harvested from early April to mid-May and the highest market prices occur before 15 May, dropping from $\approx \$ 7.00 / \mathrm{lb}$ in March to around $\$ 3.00 / \mathrm{lb}$ in May (Lyrene and Williamson, 2000; Williamson et al., 2012). Therefore, practices that improve earliness may allow growers to access higher prices in the market.

Overhead irrigation (4 to $5 \mathrm{gal} / \mathrm{min}$ per sprinkler head) is used as the preferred freeze protection method. To obtain adequate freeze protection with sprinklers, the correct amount of water needs to be applied (Locascio et al., 1967). The principle associated with this practice is called "heat of fusion" and it is described as the heat released by water during the freezing process, where $1 \mathrm{~g}$ of water releases 80 calories of heat as it forms ice (Perry, 2001; Snyder, 2001). Because of the "evaporative cooling," another property of water, as $1 \mathrm{~g}$ of water evaporates, 540 calories of heat are absorbed from the surrounding environment, thus when compared with the 80 calories released by freezing, nearly seven times more water must freeze than evaporate to provide a net heating effect (Perry, 2001). A main disadvantage of this freeze protection method is that during prolonged freezing periods, it could quickly deplete underground water sources (e.g., aquifers), which might be shared with urban settlements around the southern highbush blueberry operations. A single night of freeze protection (8 to $12 \mathrm{~h}$ of irrigation) with high volume sprinklers might use between 2 to 3

\begin{tabular}{lllc}
\hline $\begin{array}{l}\text { Units } \\
\begin{array}{l}\text { To convert U.S. } \\
\text { to SI, multiply by }\end{array}\end{array}$ & U.S. unit & SI unit & $\begin{array}{c}\text { To convert SI to U.S., } \\
\text { multiply by }\end{array}$ \\
\hline 0.4047 & acre $(\mathrm{s})$ & $\mathrm{ha}$ & 2.4711 \\
254.0000 & acre-inch/acre & $\mathrm{m} \cdot \mathrm{ha}^{-1}$ & 0.0039 \\
4.1868 & calorie $(\mathrm{s})$ & $\mathrm{kJ}$ & 0.2388 \\
0.3048 & $\mathrm{ft}$ & $\mathrm{m}$ & 3.2808 \\
3.7854 & $\mathrm{gal}$ & $\mathrm{L}$ & 0.2642 \\
0.1242 & $\mathrm{gal} / 100 \mathrm{ft}$ & $\mathrm{L} \cdot \mathrm{m}^{-1}$ & 8.0520 \\
0.4536 & $\mathrm{lb}$ & $\mathrm{kg}$ & 2.2046 \\
0.0254 & $\mathrm{mil}$ & $\mathrm{mm}$ & 39.3701 \\
1 & $\mathrm{mmho} / \mathrm{cm}$ & $\mathrm{dS} \cdot \mathrm{m}^{-1}$ & 1 \\
28.3495 & $\mathrm{oz}$ & $\mathrm{g}$ & 0.0353 \\
2.2417 & ton $/ \mathrm{acre}$ & $\mathrm{Mg} \cdot \mathrm{ha}^{-1}$ & 0.4461 \\
$\left({ }^{\circ} \mathrm{F}-32\right) \div 1.8$ & ${ }^{\circ} \mathrm{F}$ & ${ }^{\circ} \mathrm{C}$ & $\left({ }^{\circ} \mathrm{C} \times 1.8\right)+32$
\end{tabular}


acre-inch/acre of water, which might translate in very large water volumes to protect the crop (Tyson et al., 2011). Consequently, technologies aimed to save water would be desirable to reduce pressure on underground water sources, nutrient leaching potential, and pump fuel and electricity costs for growers.

The use of protective structures, such as high tunnels, has been proposed as an alternative for southern highbush blueberry freeze protection and to increase fruit earliness. High tunnels are generally unheated, plastic-covered structures with passive ventilation (Lamont et al., 2002). Potential benefits of high tunnels for vegetable and small fruit production include freeze protection, high early yields, protection against some diseases and rain, and efficient fertilizer and water use (Lamont, 2005; Ogden and van Iersel, 2009; Strik, 2012). High tunnels may increase air and soil temperatures in areas of cold weather (Kadir et al., 2006; Reiss et al., 2004). Previous research indicated that potential benefits of high tunnels for production of fruit crops, such as raspberry (Rubus idaeus), strawberry (Fragaria Xananassa), and cherry (Prunus avium). In raspberry, high tunnel production has enabled growers to extend the season during cold months and to access off-season markets during high price windows (Demchak, 2009; Gaskell, 2004). Lang (2009) examined the performance of cherry under high tunnels and found that larger sugar concentrations and fruit size were obtained when covering trees for a few weeks during fruit setting and harvesting in comparison with trees growing in the open field. Jett (2007) suggested that plants under high tunnels increased marketable fruit by $95 \%$ in contrast with only $60 \%$ in the open fields, which is mainly due to protection against rain and wind (Demchak, 2009). Pattison and Wolf(2011) demonstrated that strawberry earliness could be advanced up to 4 weeks and duplicated yields under protected culture. Kadir et al. (2006) and SalameDonoso et al. (2010) proved that strawberry leaf area and number, shoot biomass, and soluble solid content improved under high tunnels. In southern highbush blueberry, previous studies conducted in Italy, Portugal, and Japan indicated that production could be from 1 week to 1 month earlier under high tunnels compared with open-field production (Baptista et al., 2006; Ciordia et al., 2002; Ozeki and Tamada, 2006). However, there is no information on the effect of this type of structure on southern highbush blueberry fruit earliness under the subtropical Florida conditions. The objective of this study was to compare the early fruit weight of southern highbush blueberry cultivars in high tunnels and in open fields in Florida.

\section{Materials and methods}

This study was conducted over two production seasons (2009-10 and 2010-11), starting on Oct. 2009 and ending in Apr. 2011 in a commercial southern highbush blueberry farm in Waldo, FL (lat. 29 $47^{\prime} 01^{\prime \prime} \mathrm{N}$, long. $82^{\circ} 21^{\prime} 28^{\prime \prime} \mathrm{W}$ ). The soil is classified as Pomona sand (siliceous hyperthermic Ultic Alaquods). Planting beds ( $1.5 \mathrm{ft}$ tall by $4 \mathrm{ft}$ wide) were formed by placing fine pine bark chips $(\geq 1$ inch diameter) on top of the native soil and they were covered with 50-mil black groundcover. Before covering planting beds, a single irrigation drip line $(0.30 \mathrm{gal} / 100 \mathrm{ft}$ of bed per min; T-Systems International, San Diego, CA) was placed 2 to 3 inches below the top of the beds with emitters separated at $2 \mathrm{ft}$. Six-month-old 'Snow Chaser' and 'Springhigh' southern highbush blueberry plants in 2-gal containers from a local commercial nursery were transplanted in single rows with $10 \mathrm{ft}$ between rows and $2.5 \mathrm{ft}$ between plants during Spring 2004, resulting in a planting density of 1720 plants/acre. The experimental area was equipped with $4.5 \mathrm{gal} / \mathrm{min}$ sprinklers for freeze protection and the water at the experimental site has a $\mathrm{pH} 7.3$ to 7.6 and electrical conductivity (EC) between 0.4 and $0.5 \mathrm{dS} \cdot \mathrm{m}^{-1}$. For both soil $\mathrm{pH}$ and EC determination, the $1: 2$ soilto-water method was used (Mylavarapu, 2009).

Passively ventilated high tunnels (18 ft high, $25 \mathrm{ft}$ wide, $600 \mathrm{ft}$ long; Haygrove Tunnels, Redbank, UK) were built in Jan. 2006 on top of the 2-year-old plants. The structures were made of galvanized steel and maintained during the length of the experiment, while from May to August of each year, the plastic roof (6-mil thick, 35\% light reduction polyethylene; Haygrove Tunnels) and sides were completely removed from the high tunnels. Because of the historical low temperatures in this part of Florida, a single line of mini-sprinklers $(0.5$ $\mathrm{gal} / \mathrm{min}$ ) was located in each tunnel unit to aid on freeze protection. For freeze protection, the open field was equipped with sprinklers that delivered $\approx 120 \mathrm{gal} / \mathrm{min}$ per acre of water, whereas mini-sprinklers inside the high tunnels applied around $60 \mathrm{gal} / \mathrm{min}$ per acre. The irrigation system for freeze protection was turned on at $34^{\circ} \mathrm{F}$, and it was controlled independently within each production system. This temperature was chosen because Florida growers use it as a threshold point to start the sprinkler irrigation. During cold weather events, the high tunnel ends and sides were totally closed between 12 and $24 \mathrm{~h}$ before the forecast freeze and they were not ventilated until temperature reached $\approx 50{ }^{\circ} \mathrm{F}$ inside the structures. Other production practices (e.g., fertilization, irrigation, pest management) followed current recommendations for highdensity southern highbush blueberry production in Florida (Lyrene and Williamson, 2000; Williamson et al., 2012).

Four treatments were tested using combinations of two southern highbush blueberry cultivars (Snow Chaser and Springhigh) and two production systems (open fields and high tunnels). The study was conducted as a split-plot design with four replications, where the production systems were the main plots and the cultivars were in the subplots. Each high tunnel replication (three rows per tunnel) was assigned to individual units in this experimental site and they were surrounded by open fields planted with southern highbush blueberry plants submitted to the same cultural practices during the preceding years and from the same nursery and age. Openfield plots were set at least $30 \mathrm{ft}$ away from high tunnel edges, but in the same land blocks as for the tunnels to minimized weather and soil confounding effects. Plots consisted of 10 plants and early fruit weight was recorded from weekly harvests starting on 15 Feb. to 15 April of each season, totaling nine weekly harvests per season and the same plants were harvested each season. Each experimental unit was located in the middle row of each tunnel and at least $20 \mathrm{ft}$ into the structure. A marketable mature fruit was one 
without visible blemishes, disease injury, or both and with completely dark blue to purple skin. To assess the effect of high tunnels on air temperature during the coldest months of the year, temperature data loggers (HOBO; Onset Computer Corp., Bourne, MA) were installed at $3 \mathrm{ft}$ aboveground level in each high tunnel plot to record daily maximum and minimum air temperatures between September and April of each season. In the case of the open-field plots, temperature sensors were located $100 \mathrm{ft}$ south of each plot to record the actual minimum air temperatures, thus avoiding sprinkler irrigation in those plots for freeze protection. The number of days when the minimum temperature reached $34{ }^{\circ} \mathrm{F}$ or less were recorded. Collected data were analyzed using general linear model procedure to determine main factor effects and the interactions among factors (Statistix version 9; Analytical Software, Tallahassee, FL). Significantly different treatment means were compared using SE. This procedure was selected because conventional multiple comparison procedures (e.g., Duncan multiple range test, Fisher's protected least significant difference) are not appropriate for structured (continuous) data, such as harvesting dates.

\section{Results and discussion}

There was a significant difference between the production systems on the number of days with air temperatures at or near freezing, and maximum and minimum air temperatures (Table 1). However, the cultivar by production system and cultivar alone effects were not significant on these variables. In 2009-10, there were $27 \mathrm{~d}$ at $\leq 34{ }^{\circ} \mathrm{F}$ in the open-field plots in comparison with only $2 \mathrm{~d}$ with low temperatures inside the high tunnels.
During the following season, air temperatures in the plots located inside the high tunnels dropped at or below $34^{\circ} \mathrm{F}$ only once, whereas there were 34 freezing or near-freezing events in the open-field plots. The minimum air temperature in open-field plots reached $\approx 19$ and $21^{\circ} \mathrm{F}$ in the 2009 10 and 2010-11 season, respectively (Table 1 ). In contrast, the minimum air temperatures inside the high tunnels were $\approx 32$ and $33^{\circ} \mathrm{F}$, respectively, during the same seasons. This indicated that using high tunnels was an effective means to avoid freezing or near-freezing air temperatures because they prevented freezing 58 times out of $6 \mathrm{l} d$ with freezing or nearfreezing temperatures during both years, with the remaining three freeze or near-freeze events occurring around $32{ }^{\circ} \mathrm{F}$. Maximum air temperature did not differ inside and outside the structures between September and April of each year.

During the 2009-10 southern highbush blueberry season, the production system by cultivar interaction affected cumulative early fruit weight (Fig. 1A). There were no early fruit weight differences among the treatments up to 15 Mar. However, both cultivars produced in average $\approx 4.5$ tons/acre of fruit by 30 Mar. when planted inside the high tunnels, whereas there was no production in plots located in the open fields. At this point, there was no cumulative early fruit weight difference between the two cultivars. During the final harvest, the cumulative early fruit weight was the highest in plots planted with 'Snow Chaser' inside the high tunnels ( $\approx 10$ tons/acre), followed by those with 'Springhigh' under the structures $(\approx 7$ tons /acre). The combined production of these two cultivars in the open fields did not reach 1 ton/ acre until 15 Apr. 2010.
There was a significant production system by cultivar interaction effect on the cumulative early fruit weight during the 2010-11 southern highbush blueberry season (Fig. 1B). On 28 Feb. 2011, cumulative early fruit production of 'Snow Chaser' was $\approx 2.5$ tons/acre inside the high tunnels, whereas there were no differences among the other three treatments, which revealed the earliness of this cultivar under protected culture. There was no open-field production now. On 15 Mar., the cumulative early yield reached 4.5 tons/acre for 'Snow Chaser' growing inside the high tunnels, while there were no measurable early fruit differences across the other treatments, regardless of the production system. Two weeks later, the cumulative early fruit weight of 'Springhigh' inside the high tunnels was around 2 tons/acre, which was significantly higher than the yields obtained with this same cultivar in the open fields up to that harvest time (0.15 tons/acre). Still, 'Snow Chaser' production in the high tunnels surpassed 7 tons/acre by 30 Mar. On the final harvest, there were no differences on the cumulative early fruit weight of both cultivars when planted in the open fields ( 2.2 tons/ acre). The cumulative fruit yield of 'Springhigh' growing inside the high tunnels was twice as much that obtained with the same cultivar in the open fields. Moreover, 'Snow Chaser' early production under the structures was more than four times higher than the early fruit production in the open fields, which was likely due to the effect of high tunnels on flower protection and fruit setting and maturation.

These results demonstrated that using high tunnels for southern highbush blueberry production in Florida has profound effects on fruit earliness and water use for frost protection.

Table 1. Comparison of number of days at or near-freezing temperatures $\left[\leq 34^{\circ} \mathrm{F}\left(1.1^{\circ} \mathrm{C}\right)\right]$, and maximum and minimum air temperatures inside high tunnels and in open fields during the 2009-10 and 2010-11 southern highbush blueberry seasons at Waldo, FL.

\begin{tabular}{|c|c|c|c|c|c|c|}
\hline \multirow[b]{3}{*}{ Production systems } & \multicolumn{3}{|c|}{ 2009-10 season $^{\mathrm{z}}$} & \multicolumn{3}{|c|}{ 2010-11 season } \\
\hline & Time at $\leq 34^{\circ} \mathrm{F}$ & Minimum temp & Maximum temp & Time at $\leq 34^{\circ} \mathrm{F}$ & Minimum temp & Maximum temp \\
\hline & $\overline{[\text { Mean } \pm \text { SE }(d)]}$ & \multicolumn{2}{|c|}{$\left[\right.$ Mean $\left.\pm \operatorname{SE}\left({ }^{\circ} \mathrm{F}\right)\right]$} & $\overline{[\operatorname{Mean} \pm \mathrm{SE}(\mathrm{d})]}$ & \multicolumn{2}{|c|}{$\left[\right.$ Mean $\left.\pm \operatorname{SE}\left({ }^{\circ} \mathrm{F}\right)\right]$} \\
\hline High tunnels & $2 \pm 0$ & $31.6 \pm 2.2$ & $97.0 \pm 3.6$ & $1 \pm 0$ & $32.5 \pm 3.1$ & $105.5 \pm 2.4$ \\
\hline Significance $(P<0.05)^{\mathrm{y}}$ & * & * & NS & * & * & NS \\
\hline
\end{tabular}

${ }^{z}$ Temperatures obtained $3 \mathrm{ft}(0.9 \mathrm{~m})$ aboveground level from September to April of each season; during cold weather events, the high tunnel ends and sides were totally closed between 12 and $24 \mathrm{~h}$ before the forecast freeze and they were not ventilated until temperature reached $\approx 50{ }^{\circ} \mathrm{F}$ inside the structures; $\left({ }^{\circ} \mathrm{F}-32\right) \div 1.8={ }^{\circ} \mathrm{C}$.

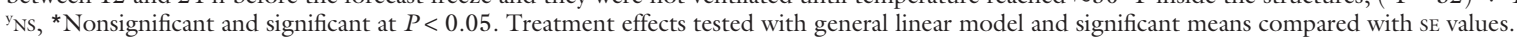



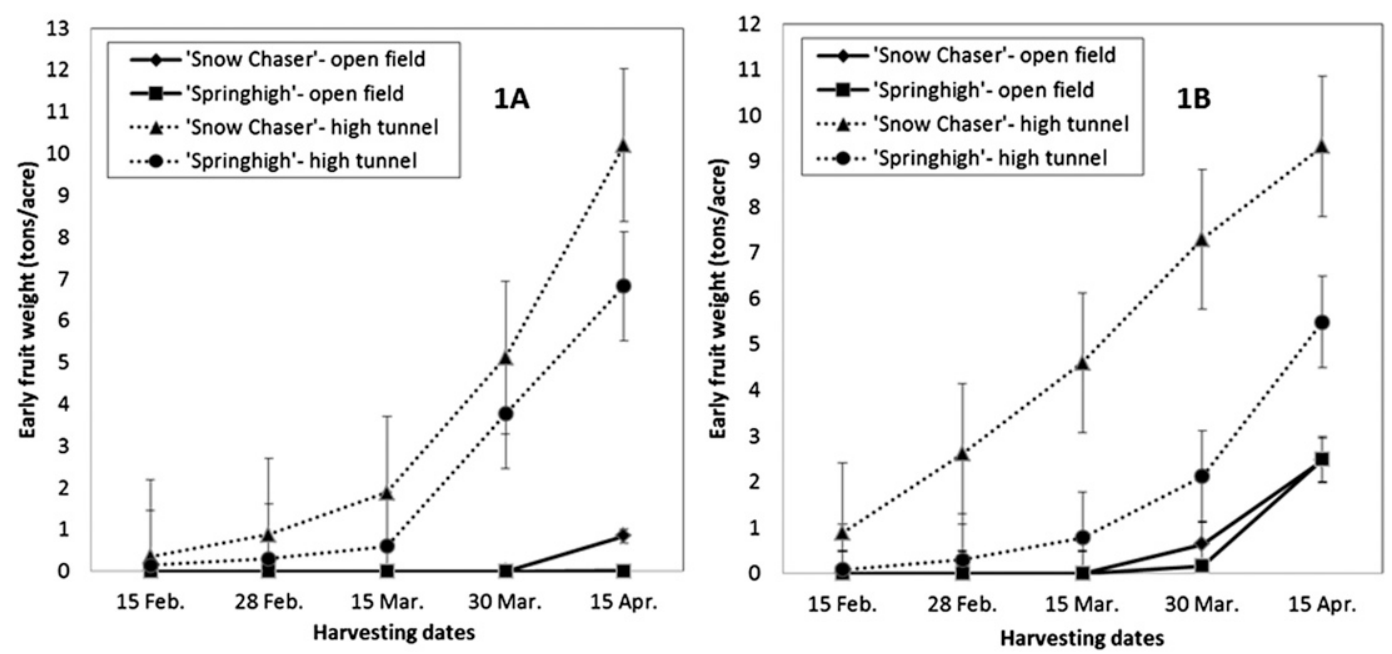

Fig. 1. Effects of production systems on the cumulative early southern highbush blueberry fruit weight at Waldo, FL in (A) 2009-10 and (B) 2010-11. Treatment effects tested with general linear model and significant means compared with SE values;

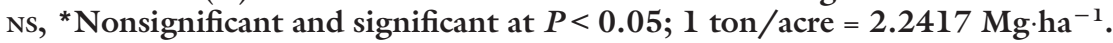

Fruit earliness increased by almost 4 weeks, especially with 'Snow Chaser'. From an environmental standpoint, high tunnels reduced water need for freeze protection. For instance, the total volume used in the open fields during the freezing or near-freezing days ( 61 events) was $\approx 2.5$ acre-inch/ acre per $8 \mathrm{~h}$ of freeze protection (120 acre-inch/acre during both seasons), whereas only $1 / 10$ of that volume was applied inside the structures. These water savings demonstrated that this method is effective for protecting young buds, flowers, and fruit against rain and ice injury, which in turn reduces the proportion of nonmarketable fruit. On the physiological side, it is also likely that the use of high tunnels and consequently the higher temperatures inside the structures allowed the plants to continue setting fruit at times when freezing temperatures were present in the open fields, which may allow growers to take advantage of high market prices during this part of the season. These results agree with those discussed by Lamont (2005) and Ogden and van Iersel (2009) on vegetables and blueberries, as well as other reports for other fruit crops, such as strawberry and raspberry (Demchak, 2009; Gaskell, 2004; Pattison and Wolf, 2011; Salame-Donoso et al., 2010). At current market prices between $\$ 18,000$ and $\$ 25,000$ per acre for high tunnels (not including labor to set up the structures), it is necessary to conduct an in-depth economic analysis to determine the actual return over time.

\section{Literature cited}

Baptista, M.C., P.B. Oliveira, L. Lopes da Fonseca, and C.M. Oliveira. 2006. Early ripening of southern highbush blueberries under mild winter conditions. Acta Hort. 446:191-196.

Ciordia, M., M. Diaz, and J. Garcia. 2002. Blueberry culture both in pots and under Italian-type tunnels. Acta Hort. 574:123127.

Demchak, K. 2009. Small fruit production in high tunnels. HortTechnology 19:44-49.

Florida Department of Agriculture and Consumer Services. 2011. 2011 Florida agriculture by the numbers. 15 May 2012. <http://www.florida-agriculture.com/ pubs/pubform/pdf/florida_agricultural_ statistical_directory.pdf>.

Gaskell, M. 2004. Field tunnels permit extended season harvest of small fruits in California. Acta Hort. 659:425-430.

Jett, L.W. 2007. Growing strawberries in high tunnels in Missouri. 14 May 2012. <http://www.hightunnels.org/PDF/ Growing_Strawberries_in_High_Tunnels. pdf>.

Joshua, T.M. 2010. 2010 Blueberry statistics. 14 May 2012. <http://www. nass.usda.gov/Statistics_by_State/New_ Jersey/Current_Releases/2010\%20NJ\% 20Blueberry\%20stats\%20book.pdf>.

Kadir, S., E. Carey, and S. Ennahli. 2006. Influence of high tunnel and field conditions on strawberry growth and development. HortScience 41:329-335.

Lamont, W.J. 2005. Plastics: Modifying the microclimate for the production of vegetable crops. HortTechnology 15: $447-481$.

Lamont, W.J., M.D. Orzolek, E.J. Holcomb, R.M. Crassweller, K. Demchak, E. Burkhart, and L. White, and B. Dye. 2002. Penn State high tunnel extension program. HortTechnology 12:732-735.

Lang, G.A. 2009. High tunnel tree fruit production. HortTechnology 19:50-55.

Locascio, S.J., D.S. Harrison, and V.F. Nettles. 1967. Sprinkler irrigation of strawberries for freeze protection. Proc. Florida State Hort. Soc. 80:208-211.

Lyrene, P.M. and J.G. Williamson. 1997. High density blueberry plantings in Florida. Acta Hort. 446:265-269.

Lyrene, P.M. and J.G. Williamson. 2000. Freeze protecting Florida blueberries. Proc. Florida State Hort. Soc. 113:28-32.

Mylavarapu, R.S. 2009. UF/IFAS extension soil testing laboratory (ESTL) analytical procedures and training manual. 12 Sept. 2009. <http://edis.ifas.ufl.edu/ SS312>.

Ogden, A.B. and M.W. van Iersel. 2009. Southern blueberry production in high tunnels: Temperatures, development, yield, and fruit quality during the establishment years. HortScience 44:18501856.

Ozeki, M. and T. Tamada. 2006. The potentials of forcing culture of southern highbush blueberry in Japan. Acta Hort. 715:241-246. 


\section{Preliminary and Regional Reports}

Pattison, J.A. and T.K. Wolf. 2011. Evaluating protected culture for season extension in small fruits. 14 May 2012. <http://www. smallfruits.org/SRSFCReserchFunding/ Research06/ProgressReport06_Pattison. pdf>.

Perry, K.B. 2001. Frost/freeze protection for horticultural crops. 23 Aug. 2011. <http://www.ces.ncsu.edu/depts/hort/ hil/hil-705.html>.

Reiss, E., A.J. Both, W. Kline, and J. Sudal. 2004. Season extension for tomato production using high tunnels. Acta Hort. 659:153-160.

Salame-Donoso, T.P., B.M. Santos, C.K. Chandler, and S.A. Sargent. 2010. Effect of high tunnels on the growth, yields, and soluble solids of strawberry cultivars in Florida. Intl. J. Fruit Sci. 10:249-263.

Snyder, R.L. 2001. Principles of frost protection. 14 May 2012. <http://biomet. ucdavis.edu/frostprotection/Principles $\% 20$ of $\% 20$ Frost $\% 20$ Protection/FP0 05 . html>.
Strik, B.C. 2012. Flowering and fruiting on command in berry crops. Acta Hort. 926:197-214.

Tyson, A.W., R.E. Sneed, C.M. Mainland, K.B. Perry, E.B. Poling, D.C. Sanders, and R. Unrath. 2011. Frost/freeze protection by sprinkler irrigation. 10 Aug. 2011. <http://www.smallfruits.org/Weather/ frost_freeze.htm>

Williamson, J.G., J.W. Olmstead, and P.M. Lyrene. 2012. Florida's commercial blueberry industry. 14 May 2012. $<$ http://edis.ifas.ufl.edu/ac031>. 